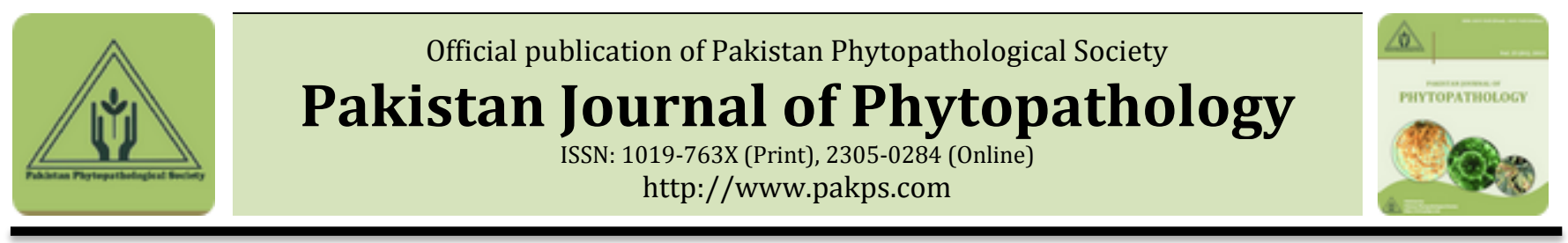

\title{
POTENTIAL RISK TO MANGO ORCHARDS: MANGO SUDDEN DECLINE CAUSED BY CERATOCYSTIS FIMBRIATA
}

\author{
aZohaib Ul Hassan*, bNadeem Nazami \\ aDepartment of Plant Protection, Ataturk University, 25240, Erzurum, Turkey. \\ ${ }^{b}$ Department of Agronomy, University College of Agriculture, University of Sargodha, Pakistan.
}

\begin{abstract}
A B S T R A C T
This review addresses one of the most emerging threats to Mango (Mangifera indica L.) production known as the Mango Sudden Decline (MSD), also referred as Mango Quick Wilt. Manifestation records of MSD/ Mango Quick Wilt have been reported from major Mango growing countries like Brazil, Oman and Pakistan where the disease is presently known to occur in mango. Fungus Ceratocystis fimbriata from family filamentous Ascomycetes vectored by Hypocryphalus mangiferae (Stebbing) bark beetle is the main cause of the disease (MSD) in Pakistan and other Mango growing regions as well. Different type of symptoms for MSD have been reported like gummosis, canker formation, bark splitting, drying of twigs, branches and curling of leaves. Hemicriconemoides mangiferae nematode has also been reported as a vector of this MSD causing fungus. This species of Ceratocystis that roots the disease on mango was first reported in Brazil after that in Oman and Pakistan. Currently, different mating types of the causative agent have also been reported making this problem a significant one. Applications of different doses of nutrients have been reported in reduction of MSD. But there is need to apply knowledge and management strategies with particular emphasis to overcome MSD causes and vectors.
\end{abstract}

Keywords: Mango Sudden Decline, C. fimbriata, Bark beetle, Filamentous Ascomycetes

\section{INTRODUCTION}

Mango Mango (Mangifera indica L.) is known as king of the fruits all over the world. It is one of most growing fruits in tropical areas including Indo-Pak (subcontinent). Mangoes produce in Pakistan have a significant impact because of their taste, flavor, deliciousness and nutritive values (Muhammad et al., 2005). Pakistan is one of the largest Mango producing countries and is ranked $5^{\text {th }}$. More than 250 cultivars have been grown over an area of 170714 hectares with the annual production of 11.086 tons/ha (FAO, 2017). Pakistan generates US $\$ 20$ million by exporting $7-10 \%$ of its total production per year (Anon, 2007). Mango (Mango, Mangosteens, Guavas) is one of the leading fruit with more than 80 million tons of annual fruit production in the world (FAO, 2017. But unfortunately, mango industry has been under threat of challenging

\footnotetext{
* Corresponding Author:

Email: zuhaib1144@gmail.com

(C) 2017 Pak. J. Phytopathol. All rights reserved.
}

problems including insect-pests, diseases, low fruit set, high fruit drop, alternate bearing and malformation etc. (Anjum et al., 1999).

Different problems which include biotic (diseases) and a-biotic (environmental stresses) lead to less production as well as economic losses. One of the most damaging, rigorous and emerging threat to Pakistan's mango industry is Mango sudden decline (MSD) also known as Mango Quick Wilt (Galdino et al., 2016) and the fungi Ceratocystis fimbriata Ellis \& Halst, is the first plant pathogen associated with it in Brazil, Oman and Pakistan (Ribeiro 1980; Malik et al., 2005; Al Adawi et al., 2006; Saeed \& Masood, 2008; Oliveira et al., 2015). Three fungal pathogens are reported as Ceratocystis fimbriata, C. omanensis, and Lasiodiplodia theobromae, with the MSD in Oman. (Van Wyk et al., 2007) suggested Ceratocystis manginecans as the causative agent of MSD in Oman and Pakistan. Ceratocystis manginecans is not a new species and is closely related to $C$. fimbriata (VanWyk et al., 2007). 
Mango sudden decline (MSD) is known as one of the most destructive threats in Pakistan as well as all mango growing areas of the world (Kazmi et al., 2005). MSD has been reported from various districts of Pakistan with incidence of 10-28\% in Punjab (Asif et al., 2011). Thousands of mango trees in Pakistan have been affected by this destructive disease, which are causing high economic losses to mango production (Jiskani, 2006). Different type of symptoms for MSD have been reported like gummosis, canker formation, bark splitting, drying of twigs, branches and curling of leaves (Al Adawi et al., 2006; Al-Subhi et al., 2006; Masood et al., 2010).

CAUSES AND VECTOR: Typical symptoms of MSDS have been reported in mango plants after inoculation with Lasiodiplodia theobromae and this fungus was frequently isolated from declining mango trees and bark beetle in Pakistan (Saeed et al., 2008; Shahbaz et al., 2009). In spite of these pathogenic fungi Ceratocystis fimbriata, Ceratocystis manginecans, Lasiodiplodia theobromae and bark beetle species arenvolved as putative vectors (Ribeiro, 1980; Al Adwai et al., 2006; Masood et al., 2008). Many fungal pathogens belonging to genus Ceratocystis have an intimate association with scolytid beetles which may play very significant role as vectors (Moller \& Devay, 1968). Young beetles emerging from infective trees are mostly contaminated with fungal spores and then inoculate healthy host trees when feeding on the bark (Fransen \& Buisman, 1935; Webber $\&$ Gibbs, 1989). The process of vector was stated as the beetle produces galleries in the cambium of affected trees, feeding primarily on fungi and serving as a wounding agent that facilitates infection and transmission of the pathogens (Ploetz, 2003). Several bark beetle species have developed mycangia in different location on body which carry inoculum during migration (Six, 2003; Harrington, 2005), i.e. adult female of Xyleborus glabratus (Coleoptera: Scolytidae) has mycangia near mandible while Xyleborus sp., have similar structures at the base of elytra and intersegmental sacs between pronotum or mesonotom (Fraedick et al., 2008). Besides these threats, some other associated problems also make the situation much troublesome for the growers of mango. This is a complex problem, and is difficult to manage due to the insect-pest nature of the disease (Keerio, 2005). Hemicriconemoides mangiferae nematode can also be the vector by making the root of plant weak and gives openings for different soil borne fungi to attack by inducing different physiological changes. (Aatif and Zohaib, 2015).

Taxonomy of C. fimbriata: Ceratocystis fimbriata belongs to filamentous ascomycetes. The vegetative hyphae that form the mycelium typically are hyaline to dark olive-green, septate, branched, and smooth walled. This fungus can reproduce both sexually and asexually, and when grown on artificial media, it abundantly produces both asexual spores (conidia) and sexual spores (ascospores). Ceratocystis species are ascomycete fungi residing in the order Microascales (Schoch et al., 2009; Réblová et al., 2011). The data of DNA sequencing and molecular phylogenetics have profoundly impacted on the taxonomy of this group of fungi, starting with the recognition of $C$. albifundus as a novel species, distinct from C. fimbriata Ellis \& Halst. (Wingfield et al., 1996). One of these will accommodate species in the $C$. fimbriata complex that includes C. albifundus and many other, mainly pathogenic species (Baker et al., 2003; Johnson et al., 2005; Van Wyk et al., 2013).

Mating Types: Mostly ascomycetes are known to be heterothallic. In Ascomycetes for sexual reproduction two compatible haploid cells of different mating types fuse to form a dikaryon are required, which becomes diploid and undergoes meiosis. Like other Ascomycetes two distinct types of mating are also present in $C$. fimbriata, MAT-1 and MAT-2, determined by two idiomorphs at the mating type locus (Harrington and McNew, 1997). Because of uni-directional mating type switching (Harrington and McNew 1997, Witthuhn et al., 2000), a MAT-2 isolate may delete the MAT-2 gene and express MAT-1, being self-sterile (obligately outcrossing). Both mating types are represented in the sexual progeny of self-fertile cultures (Witthuhn et al., 2000), but MAT-1 strains are less common in nature than MAT-2 strains, and they also grow more slowly and are less able to cause disease (Harrington and McNew 1995; Olson and Martin, 1949).

Host Range: The fungal pathogen Ceratocystis fimbriata Ell. \& Halst., causes serious wilt and canker-stain diseases on a wide range of plants world-wide. Degree of susceptibility and the rate at which they become infected differ for susceptible host specie. For example, the symptoms in cacao trees infected by $C$. fimbriata developed within seven days, while sweet potato and coffee plants in the same study, infected with the same isolate, expressed symptoms after twenty-one days (Giraldo, 1957). Individuals within one plant species 
may vary to each other in their susceptibility to pathogenic strains of $C$. fimbriata (Przybyl 1984a; Small 1967), which makes breeding for resistance possible (Greene and Lowe 1992; Dominguez and Velasquez 1972; Dominguez 1976). Transmission of Ceratocystis fagacearum (Brentz) Hunt, caused oak wilt was intensively studied in North America whereby nitidulid beetles attracted by exuding sap, carry $C$. fagacearum to wounded oak and such wounds provide ground as infection courts (Gibbs \& French, 1980). Hence therefore, there is a lot of study concerning with the possible host-specificity of many $C$. fimbriata strains is present but Unfortunately, many of these studies examined only one fungal isolate from each plant host and failed to report the location from which the fungus was originally collected.

Plant Defense against $\boldsymbol{C}$. fimbriata: A very few studies have been done to examine constitutive plant defenses against $C$. fimbriata. These studies included mechanisms of resistance within host species; for example, phenolic compounds are more abundant in the leaves and branches of resistant cacao cultivars than in those of susceptible ones (Reyes and Reyes, 1968). Induced defenses such as phytoalexins (El Modafar et al., 1995), tannins, and cork layers around phloem (Przybyl, $1984 b$ ) are also present in poplars and sycamores inoculated with C. fimbriata. Kojima (1993) reported that a combination of phytoalexins, calcium ions, and spore-agglutinating factors in plants, and sporeagglutination inhibitory proteins on germinated spores; determine host-pathogen specificity in C. fimbriata. Host defenses may be controlled by different mechanisms in different host species, and therefore, the mechanisms of host-specificity of the fungus may vary greatly depending on the plant host.

Management Strategies of MSD: Nutrients have significant role in inducing the tolerance by stability and strengthening of the cell walls which is assumed to be first line of defense against fungal diseases like mango sudden decline. The maximum reduction has been reported up-to $30.69 \%$ in disease severity with nutrients application of $\mathrm{ZnSO} 4+\mathrm{CuSO} 4+\mathrm{NP}+$ humic acid while application by $\mathrm{ZnSO} 4+\mathrm{FeSO} 4+\mathrm{NP}+$ humic acid and CuSO4+NP+humic acid have been reported as $19.51 \%$ and $19.37 \%$, respectively. Only the application of nitrogen and phosphorus without micronutrients have been reported to reduce the minimum disease severity of $8.39 \%$ followed by $9.35 \%$ when combined all nutrients i.e. $\mathrm{Zn} \mathrm{SO4+} \mathrm{FeSO4+CuSO4+NP+humic} \mathrm{acid}$ (Masood, 2012).

\section{SUMMARY AND CONCLUSIONS}

As mango is one of the economically important fruit for Pakistan due to its exportation throughout the world and gaining currency to homeland and most exported fruits of Pakistan. Mango sudden decline emerges as the devastating disease which can make losses to crop as well as the GDP of the country. Different vectors and mating types have also been reported that make us to the alarming situation. There is need to manage this important disease through Integrated Disease Management strategies (IDM). Different doses of nutrients have been reported in reduction of disease, but integrated pest management strategies including application of knowledge of pathogen, vector's biology and ecology, chemical and nutrient applications can be effective in reduction of this devastating disease.

\section{REFERENCES}

Aatif and Zohaib. 2015. Mango Sudden Decline (A Syndrome of Mango Orchards). Daily Patriot http://dailythepatriot.com/e-paper/.

Al Adawi, A.O., M. L. Deadman, A. K. Al Rawahi, Y. M. Al Maqbali, A. A. Al Jahwari, B. A. Al Saadi, I. S. Al Amri and M. J. Wingfield. 2006. Aetiology and causal agents of mango sudden decline disease in the Sultanate of Oman. Eur. J. Plant Pathol. 116(4): 247-254.

Al Subhi, A. M., A. O. Al Adawi, M. vanWyk, M. L. Deadman and M. J. Wingfield (2006). Ceratocystis omanensis, a new species from diseased mango trees in Oman. Mycological Res. 110: 237-245.

Anjum, M. A., Chatha, G. A., Sultan, M. and Abbas, S. 1999. Flowering behavior, fruit setting and extent of mango malformation. Int. J. Agri. Biol. 1(3): 88-90.

Anonymous. 2007. Economic Survey of Pakistan. Accountancy- Accounting and Finance News, Articles and Forums (www.accountancy.com.pk): 15-25.

Asif, I., F. S. Faisal, K. R. Munawar, A. N. Chrys, P. Gulbhar and L. H. Nazim., 2011 Trend of mango sudden death syndrome (MSDS) in relation to fungal microflora and nematodes fauna in Punjab, Pakistan. Pak. J. Nematology. 29 (1): 45-51.

Baker, C. J., T. C. Harrington, U. Krauss, A. C. Alfenas. 2003. Genetic variability and host specialization in the Latin American clade of Ceratocystis fimbriata. Phytopathol. 93: 1274-1284. 
Dominguez, P. F. and F. Velasquez. 1972. Seleccion de plantas de cacao (Theobroma cacao L.) por resistencia al hongo Ceratocystis fimbriata. Rev. Fac. Agron. 6: 57-73.

Dominguez, P. F. 1976. Relacion entre vigor de las plantas y resistencia al hongo Ceratocystis fimbriata en cacao. Rev. Fac. Agron. 9: 5-21.

El Modafar, C., A. Clerivet and J. J. Macheix. 1996. Flavan accumulation in stems of Platanus $\mathrm{X}$ acerifolia seedlings inoculated with Ceratocystis fimbriata f.sp. platani, the canker stain disease agent. Can. J. Bot. 74: 1982-1987.

Fransen, J. J. and C. Buiman. 1935. Infestieproeven op verschillende iepensoorten met behulp van iepenspintkevers. Tijdsch. Over Plantenzickten, 41: 221-239.

FAO, 2017. FAO Stat. Food and Agricultural Organization of The United Nations. http://www.fao.org, Date of visit: $10^{\text {th }}$ May 2017.

Fraedick, S. W., T. C. Harrington, R. J. Rabaglia, M. D. Ulyshen, A. E. Mayfield, J. L. Hanula, J. M. Eickwort and D. R. Miller. 2008. A fungal symbiont of the redbay ambrosia beetle causes a letalh wilt in redbay and other lauraceae in the southeastern United States. Pl. Dis. 92(2): 215-224.

Galdino, T. V. da S., S. Kumar, L. S. S. Oliveira, A. Alfenas, L. G. Neven, A. M. Al-Sadi, \& M. C. Picanço. 2016. Mapping Global Potential Risk of Mango Sudden Decline Disease Caused by Ceratocystis fimbriata. PLoS ONE, 11(7), e0159450. http://doi.org/10.1371/journal.pone.0159450.

Giraldo, E. A. 1957. La llaga macan del tronco del cacao. Acta Agronomica 7:71- 103.

Gibbs, J. N. and D. W. French. 1980. The transmission of oak wilt. U.S. Forest Service, Minnesota. Res. Pap. NC-185.

Greene, T. A. and W. J. Lowe. 1992. Changes in the pattern of genetic variability over time in American sycamore and the implication for early selection. Can. J. For. Res. 22:713-717.

Harrington, T. C. 2005. Ecology and evolution of mycophagous bark beetles and their fungal partners. In: Insect-Fungal Associations: Ecology and Evolution. (Eds.): F. E. Vega and M. Blackwell. Oxford University Press, Inc. New York: 257-292.

Harrington, T. C., J. Steimel and G. Kile, G. 1998. Genetic variation in three Ceratocystis species with outcrossing, selfing and asexual reproductive strategies. Eur. J. For. Path. 28: 217-226.

Irene, B., 2001. Microsatellite markers reflect intraspecific relationships between isolates of the vascular wilt pathogen Ceratocystis fimbriata. Mol. Pl. Pathol. 2(6): 319-325.

Jiskani, M. M. 2006. Ball formation: a new threat to mango growers. Hortimag. A newsletter of Pakistan Horticulture Development Board. $7 \mathrm{p}$ (www.phdb.org.pk).

Johnson J. A., T. C. Harrington, C. J. B. Engelbrecht. 2005. Phylogeny and taxonomy of the North American clade of the Ceratocystis fimbriata complex. Mycologia 97, 1067-1092.

Kazmi, M. R., F. S. Fateh, K. Majeed, A. M. Kashkhely, I. Hussain, I. Ahmad and A. Jabeen. 2005. Incidence and etiology of mango sudden death phenomenon in Pakistan. Pak. J. Phytopathol. 17(2): 154-158.

Keerio, H. K. 2005. Mango Decline: Causes and Management. Pakissan, Monday Available at www.pakissan.com/english/news/newsDetail.ph p?newsid=6898.

Kojima, M. 1993. Phytoalexins and other biochemical factors associated with infection by Ceratocystis fimbriata. pp. 243-251 in Ceratocystis and Ophiostoma: Taxonomy, Ecology, and Pathogenicity. Ed. M. J. Wingfield, K. A. Seifert, and J. F. Webber. St. Paul, MN: A. Phytopathol. Soci.

Malik, M. T., A. A. Dasti and S. M. Khan. 2005. Mango decline disorders prevailing in Pakistan. Proceedings of International Conference on Mango and Date palm: Culture and Export, University of Agriculture, Faisalabad, Pakistan. 2023-June: 25.

Muhammad. 2005. Growth of mango cv. Langra as influenced by pruning of malformed panicles. Pak. j. life soc. Sci. 3(1-2): 24-27.

Masood, A., S. Saeed, N. Erbilgin and Y. J. Kwon. 2010. Role of stressed mango host conditions in attraction of and colonization by the mango bark beetle Hypocryphalus mangiferae Stebbing (Coleoptera: Curculionidae: Scolytinae) and in the symptom development of quick decline of mango trees in Pakistan. Ento. Res. 40: 316-327.

Masood, A., Saeed, S., Mahmood, A, Malik A, Hussain, N, 2012. Role of Nutrients in Management of Mango Sudden Death Disease in Punjab, Pakistan. Pak. J. of zoology Volume: 44 Issue:3 Pages: 675-683 
Moller, W. J. and J. E. DeVay. 1968. Carrot as a speciesselective isolation medium for Ceratocystis fimbriata. Phytopathol. 58: 123-124.

Olson, E. O. and W. J. Martin. 1949. Relationship of Ceratostomella fimbriata from Hevea rubber tree and sweet potato. Phytopathol. 39: 17.

Oliveira, L. S., T. C. Ferreira, M. B. Damacena, A. M. AlSadi, I. H. Al-Mahmooli, A. C. Alfenas. 2015. Species or Genotypes? Reassessment of Four Recently Described Species of the Ceratocystis Wilt Pathogen, Ceratocystis fimbriata, on Mangifera indica. Phytopathol. 105: 1229-1244.

Przybyl, K. 1984a. Development of the fungus Ceratocystis fimbriata in shoots of poplar clones with differing resistance. Eur. J. For. Path. 14: 177-183.

Przybyl, K., 1984b. Pathological changes and defense responses in poplar tissues caused by Ceratocystis fimbriata. Eur. J. For. Path. 14: 183-191.

Ploetz, R. C., D. Benscher, A. Vazquez, A. Colls, J. Nagel and B. Schaffer. 1996. A re-evaluation of mango decline in Florida. Plant Dis. 80: 664-668.

Ribeiro, I. J. A., 1980. Seca de manguera. Agentes causais e studio da molesta. In: Anais do I Simposio Brasiliero Sobre a Cultura de Mangeura. Sociedad Brasileira de Fruticultura, Jacoticobal: 123-130.

Réblová M., Gams W, Seifert K. A. 2011. Monilochaetes and allied genera of the Glomerellales, and a reconsideration of families in the Microascales. Studies in Mycol. 68: 163-191.

Reyes, L. C. de, and Reyes, H., 1968. Contenido de polifenoles en dos variedades de Theobroma cacao L. y su relacion con la resistencia a Ceratocystis fimbriata. 18: 339-355.

Saeed, S. and A. Masood. 2008. Association of Bark beetle Hypocrphalus mangiferae Stebbing (Coleptera: Scolytidae) with pathogens Ceratocystis fimbriata and Phompsis sp., in relation to Mango Sudden Death in Pakistan. International conference, 93rd ESA Annual Meeting, Milwaukee, Wisconsin August 3-8, 2008 USA.

Saeed, S. and A. Masood. 2008. Association of Bark beetle Hypocrphalus mangiferae Stebbing (Coleptera: Scolytidae) with Pathogens Ceratocystis fimbriata and Phompsis sp., in relation to Mango Sudden Death in Pakistan. International conference, 93rd
ESA Annual Meeting, Milwaukee, Wisconsin August 3-8, 2008 USA.

Shahbaz, M., Z. Iqbal, A. Saleem and M. A. Anjum. 2009. Association of Lasiodiplodia theobromae with different decline disorders in Mango (Mangifera indica L.). Pak. J. Bot. 41(1): 359-368.

Six, D. L. 2003. Bark beetle-fungus symbioses. In: Insect Symbiosis. (Eds.): K. Bourtzis and T. Miller. CRS Press. Boca Raton FL: 99-116.

Schoch, C. L., G. H. Sung, G. F. Lopez, J. P. Townsend J. Miadlikowska J. V. Hofstetter. 2009. The Ascomycota tree of life, A phylum-wide phylogeny clarifies the origin and evolution of fundamental reproductive and ecological traits. Syst. Bio. 58: 224-239.

Small, L. W. 1967. Ceratocystis resistance test. Annual Report on Cacao Research, 1966. St. Augustine, Trinidad: Imperial College of Tropical Agriculture: 40-48.

VanWyk, M., B. D. Wingfield M. J. Wingfield. 2013. Ceratocystis species in the Ceratocystis fimbriata complex. In: Seifert KA, Wingfield MJ (Eds), The Ophiostomatoid Fungi, Expanding Frontiers. Biodiversity Series 12 CBS, Utrecht: 65-76.

Van Wyk, M., A. O. Al Adawi, I. A. Khan, M. L. Deadman, A. A. Al Jahwari, B. D. Wingfield, R. Ploetz and M. J. Wingfield. 2007. Ceratocystis manginecans sp. nov., causal agent of a destructive mango wilt disease in Oman and Pakistan. Fungal Diversity. 27: 213-230.

Webber, J. F. and J. N. Gibbs. 1989. Insect dissemination of fungal pathogens of trees. In: Insect-fungus interactions. (Eds.): N. Wilding., N.M. Collins, P.M. Hammond and J. F. Webber. Academic Press, London: 160-175.

Wingfield M. J., C. Beer, C. Visser, B. D. Wingfield. 1996. A New Ceratocystis species defined using morphological and ribosomal DNA sequence comparisons. Systematic and Appl. Microbiol. 19: 191-202.

Witthuhn, R. C., T. C. Harrington, B. D. Wingfield, J. P. Steimel, and M. J. Wingfield. 2000. Deletion of the MAT-2 mating-type gene during uni-directional mating-type switching in Ceratocystis. Curr. Genet. 38: $48-52$. 